\title{
Perceived Organizational Injustice and Corrupt Tendencies in Public Sector Employees: Mediating Role of Life Satisfaction
}

\author{
Bolanle Ogungbamila $^{1 *} \&$ Bulous Florence Ojogo ${ }^{1}$ \\ ${ }^{1}$ Department of Pure and Applied Psychology, Adekunle Ajasin University, Nigeria
}

Received 23.08.2020; Received revised 22.12.2020; Accepted 23.12.2020

Available online 31.12.2020

\begin{abstract}
Studies have shown that corruption may adversely affect the functionality of the law and institutions; and may frustrate socio-economic development. Most developing countries focus the fight against corruption on the deterrence perspective, which emphasizes the promptness and severity of punishment as a way of preventing and discouraging corrupt behaviors. Punishment may not adequately deter corruption, especially when employees are less satisfied with life or feel unjustly treated and may, therefore, engage in corruption as a justice-restoring act. This study, therefore, adopted a justice-focused approach to investigate the extent to which perception of organizational injustice and life satisfaction correlated with corrupt tendencies in public sector employees. The participants were 285 public sector employees (188 males; 97 females), whose ages averaged 39.09 years $(S D=8.40)$ with a range of 20 to 58 years. They were selected across large sections of two public sector organizations in Nigeria. Results of the 3-step hierarchical regression showed that perception of organizational injustice was significantly related with increased level of corrupt tendencies. As the participants' level of life satisfaction increased, their tendencies of engaging in corruption reduced. Results of the mediation tests showed that, despite an increased perception of organizational injustice, life satisfaction was significantly related with low tendencies of engaging in corruption among employees. In order to reduce corrupt tendencies, organizations should efficiently handle perceived wrongdoing among employees and institute programmes that promote employees' happiness and well-being.
\end{abstract}

Keywords: Injustice, life satisfaction, corruption, public sector, Nigeria.

Address of correspondence: Bolanle Ogungbamila $(\mathrm{PhD})$, Department of Pure and Applied Psychology, Adekunle Ajasin University, PMB 001 Akungba-Akoko, 34-234 Ondo State, Nigeria.

E-mail: bolanle.ogungbamila@aaua.edu.ng

\section{Introduction}

Studies (e.g. Heidenheimer, 2013; Johnston, 2010; Rijckeghem \& Weder, 2014) have shown that corruption adversely may affect the functionality of the law and institutions; and may frustrate socio-economic development. For example, the World Bank has identified corruption as the single greatest clog to economic and social development (World Bank Report, 2012). Specifically, strong links have been reported among corruption, inequality, poverty and economic growth (Adegboyega, 2017; Rabnawaz, 2015; Sunkanmi \& Isola, 2014; Yunan \& Andini, 2018). According to Omenka (2013), corruption has strong connections with low economic development, huge levels of poverty and inequality because corruption may affect the formulation and implementation of development policies and reduces employees' levels of efficiency, commitment, well-being (Rijckeghem \& Weder, 2014; Šumah, 2018) and hinders organizational performance (Lambsdorff, 2010; Saithibvongsa \& JinKyo, 2019).

The concern of this study was to investigate corruption from the angle of employees. This is because the human elements in every organization are usually charged with the responsibility of formulating, driving, and implementing development policies of the organization. Are employees corrupt because they perceive injustice and are unsatisfied with life? Or the other way round? This study focused the first question. When employees feel justly treated by the organization and are generally satisfied with life, their tendencies to engage in corruption may reduce. Since the total eradication of corruption may not be possible, it may be beneficial to investigate corruption by looking at employees' corrupt tendencies. An understanding of 
employees' corrupt tendencies or proclivity toward corruption would serve a preventive purpose in the anticorruption crusade, which is less expensive compared with the investigation, prosecution, and punishment of corrupt persons, and recovery of stolen assets as well as undoing the damages brought about by corrupt practices.

Corrupt tendencies refer to the inclination to engage in dishonest practices that lacks integrity (Kaufmann, 1997) in order to benefit self and relevant others at the expense of the organization, other organization members (Ogungbamila, 2017), and the society. Employees' tendencies to engage in corruption may be initiated, ignited, and sustained by individual and organizational or situational factors. In the case of personal variables, corrupt tendencies may not be restricted to employees in a particular age, gender, job level, or academic qualification. This is because there were no strong age, gender, job level, academic qualification, and job tenure differences in the level of corrupt tendencies among public sector employees in Nigeria (Ogungbamila, 2017; Ogungbamila \& Udegbe, 2014; Onifade \& Bodunde, 2009). However, studies (e.g. Fišar, Kubák, Špalek and Tremewan, 2016; ŻemojtelPiotrowska, Marganski, Baran, \& Piotrowski, 2017) showed that women were less susceptible to corruption than men.

Employees' personality characteristics, such as extraversion (Agbo \& Iwundu, 2016), narcissism, psychopathy, Machiavellianism (Zhao, Zhang \& Xu, 2016), and pretentious moral disposition (Abraham, Suleeman \& Takwin, 2018), were connected with increased level of corrupt tendencies. Other personality characteristics that are rooted in value orientation such as meritocratic and materialist values, have been linked with corrupt tendencies (Julián \& Bonavia, 2020). For example, $\mathrm{Tu}$, Yang and Zheng (2020) reported that Chinese civil servants' value orientation (power distance, collectivism, uncertainty avoidance, and masculinity) determined their level of corruption tolerance and willingness to participate in anti-corruption crusade. They found that employees who were high on collectivism or masculinity tended to show higher corruption tolerance and lower readiness to partake in anti-corruption activities. However employees who showed high level of uncertainty avoidance were less tolerant of corruption and were more willingness to get involved in anti-corruption crusades (Tu et al., 2020).

Julián and Bonavia (2020) submitted that corrupt practices do not take place in a vacuum. Situational factors in corrupt tendencies have been investigated. Results of situational factors in corruption indicate that employees exhibit corrupt tendencies within socio-cultural, organizational, economic and political contexts, which may either stoke or discourage the inclination to engage in corruption (Rabl, 2011; Türedi \& Altiner, 2016). For example, organizational factors, such as organizational ethics and leadership behaviours (Hechanova, Melgar, Falguera \& Villaverde, 2014), that direct the formulation and implementation of ethical standards, are important in stemming acts of corruption because when “... these corrupt practices are forgiven, authorized, allowed, or rewarded, it is more likely that the members of the organization will continue in this direction" (Julián \& Bonavia, 2020, p. 333). Consequently, when employees perceive that corruption is widespread in the organization, high beneficial, acceptable by peers, and with little or no negative social or legal consequences, their tendencies to engage in corruption would increase (Dong, Dulleck \&
Torgler, 2012; Dupuy \& Neset, 2018; López-López, Bocarejo, Peralta, Pineda \& Mullet, 2017).

The assumption that employees run a cost-benefit analysis (Cook, 1982; Gibbs, 1975) before engage in corruption may be an important situational factor but not in all circumstances. For example, in a study involving public and business employees, Gorsira, Denkers and Huisman (2018) reported that the cost-benefit analysis did not strongly predict employees' corrupt tendencies. They suggested that studies should focus on other motives of corruption that are beyond the cost-benefit hypothesis of corruption. This implies that employees' corrupt tendencies may be driven by other motives such as using corruption as the vehicle to protesting injustice or restoring justice, especially when they perceive a negative imbalance in the effort-reward ratio (Siegrist, 2000; 2002), especially where there is widespread and an increasing incidence of effort-reward imbalance with its attendant psychological and health effects on the employees (Leineweber, Eib, Bernhard-Oettel \& Nyberg, 2019).

Specifically, the effort-reward imbalance assumes that employees expend efforts, time, and other resources at work based on the tenet of social reciprocity, which guarantees that the organization would provide commensurate rewards such as money, social recognition, career opportunities, and job security (Siegrist, Starke, Chandola, Godin, Marmot, Niedhammer \& Peter, 2004). In reality, most organizations do not provide the rewards that are commensurate with the efforts expended by employees. In such case, the employees may leave the organization in order to escape the negative consequences associated with prolonged and recurrent effort-reward imbalance. However, high rate of unemployment may either force those employees into "overcomitment" (Siegrist et al., 2004) or engage in lip-service while they remain in the organization, despite the high effort-reward imbalance. Such employees may feel justified to engage in corruption and may see corruption as a justice-restoring behavior aimed at taking what belongs to them from the organization. Other employees may not feel compelled to engage in corruption despite the effort-reward imbalance. Their level of life satisfaction may dampen the level at which the perception injustice, brought about by the effortreward imbalance, lead to corrupt tendencies. This study aimed to investigate the level at which perception of organizational injustice predicts corrupt tendencies and whether life satisfaction moderates such relationship.

\section{Perception of organization injustice and corrupt tendencies}

The relationships between perception of organizational injustice and corrupt tendencies have been investigated. When employees perceive injustice they may form retaliatory intentions toward the perpetrators of the injustice. Goergen, Pauli, Cerutti and Perin (2018) investigated the extent to which perceived justice led to retaliatory attitudes among 163 employees in a multinational agricultural manufacturing company located in the north region of Rio Grande do Sul State, Brazil. They also studied how organizational trust affected the relationship between perceived justice and retaliatory attitudes. Results showed that when employees felt justly treated by the organization and its agents they formed less retaliatory attitudes towards the organization. Retaliatory attitudes increased as perception of organizational injustice increased. However, when employees had trust in the organization, their level of retaliatory attitudes reduced 
despite the perception of injustice (Goergen, et al., 2018). This implies that trust enabled the employees to exonerate the organization from the perceived injustice or gave the organization another opportunity to redeem itself and restore the balance of justice.

In a study that involved 225 police personnel in Nigeria, Ojedokun (2010) reported that effort-reward imbalance was significantly related with increased tendencies to engage in unethical behavior. Therefore, corruption may serve a justice-restoring motive, especially when rewards do not equate or approximate the expended efforts. Other studies have also implicated corruption as a possible reaction to perceived injustice. For example, Ogungbamila and Udegbe (2014) studied corruption as a form of workplace reactivity to perceived organizational injustice. The participants were 703 employees sampled from six states in southwestern Nigeria. They found that employees' corrupt tendencies increased with their level of perception of organizational injustice. They concluded that corrupt tendencies were revenge motivated behavior aimed at protesting and avenging perceived injustice and aimed at restoring the balance of justice in the workplace.

Perception of organizational injustice has also been linked with counterproductive work behavior, which covers theft, fraud, withdrawal behavior, and sabotage, targeted at thwarting the goals with negative manifestations on the organization, other employees, and customers of the organization (Spector, Fox, Penney, Bruursema, Goh \& Kessler, 2006). Like corruption and other forms of workplace reactivity, a primary motive of counterproductive work behavior could be to make the organization and other perceived perpetrators of injustice pay for their unjust actions that are connected with effortreward imbalance suffered by employees. To test this hypothesis, Dajani and Mohamad (2017) investigated the connections between perception of organizational injustice and counterproductive work behavior in 236 public sector employees in Egypt. They reported that perception of organizational injustice significantly increased employees' tendencies to engage in counterproductive work behavior. This implies that the more employees feel unjustly treated the more the likelihood that they would respond with injurious behaviors toward the perceived perpetrators of the injustice (e.g. corruption and counterproductive work behavior), which are revenge-motivated.

In a study that involved 420 employees, selected from a public university in Isfahan, City-Iran, Danaeefard and Boustani (2016) found that employees, who perceived justice, reported low level of cynicism and behaved in less corrupt manner toward their organization than those who felt unjustly treated. In other words, perception of organizational injustice increased employees' level of callousness and insensitivity to the health and survival of the organization. At that stage, the employees' level of misbehavior, which encompasses forms of corruption such as fraud, theft, abuse of office, and waste of the organization's resources, increased significantly. This implies that perception of organizational injustice ignited revenge-motivation and provided rationalization for employees' insensitivity and corruption at work.

Taking the revenge-motivated hypothesis of corrupt tendencies further, Ogungbamila (2017), in two (vignette and questionnaire) studies, investigated how perception of organizational injustice laden with opportunities to justify corruption (workplace neutralization) affected employees' corrupt tendencies (vignette study) and the linear connection of perception of organizational injustice and workplace neutralization with corrupt tendencies (questionnaire study) in Nigerian employees. Results showed that perception of organizational injustice increased employees' corrupt tendencies, especially when the employees had opportunities to justify their intended acts of corruption. In other words, workplace neutralization successfully helped the aggrieved employees to turn corruption into a revenge-motivated behavior against injustice; thereby making corruption an acceptable behavior. Therefore, when employees are able to cognitively transform corruption into an acceptable behavior (Dupuy \& Neset, 2018) aimed at restoring justice, they may be less bordered by the legal and social punishments against corruption, and their tendencies to engage in corruption would increase. It was, therefore, hypothesized that:

Hypothesis 1: Perception of organizational injustice will be significantly related with an increased level of corrupt tendencies among employees.

\section{Life satisfaction and corrupt tendencies}

Apart from the adverse effects of corruption on national and organizational development, a strong connection may exist between corruption and life satisfaction. Life satisfaction refers to individuals' subjective evaluation of his or her life in relation to how well his or her goals and aspiration have been met (Diener Oishi \& Lucas, 2003; Pavot \& Diener, 2008). Therefore, employees' cognitive and emotional evaluations of how satisfied with their present condition in life depend on how well the perceived present state of affairs measures up to a personal standard set by the individual. The outcome of, and reaction to, such evaluations may determine whether or not the employees would be happy and satisfied with life or unhappy and dissatisfied with life; which may prompt those who are unhappy to engage in behaviors (e.g. corruption) that are targeted at (a) those who are responsible for the current state of affairs and (b) improving the state of affairs to approximate the personal standard.

Studies (e.g. Ngamaba, 2014; Tay, Herian \& Diener, 2014; Wu \& Zhu, 2016) have investigated the relationship between life satisfaction and corruption. Tay et al. (2014) reported that life satisfaction reduced with perception of corruption. The concern about corrupt practices might have reduced the level of cognitive resources employees in corrupt workplace devote to caring about their health and subjective well-being, especially if the concerns are predicated on effort-reward imbalance (Leineweber et al., 2019). Perception of corruption may be connected with trust in institutions within and outside an organization, especially those that involved with the investigation and prosecution of corruption-related issues as well as those that compensate and distribute rewards for employees' efforts in organizations. Ciziceno and Travaglino (2019), in two studies, tested the mediatory roles of institutional trust on the extent to which corruption perception affected life satisfaction. They found across the two studies that perception of corruption indirectly led to low life satisfaction by reducing the individuals' trust in institutions. That is when individuals perceived low corruption in their environment their trust in institutions was high, which increased their level of life satisfaction.

Perception of corruption and participation in corrupt activities may exert different effects on life satisfaction. $\mathrm{Wu}$ and $\mathrm{Zhu}$ (2016) found that participation in corruption 
led to low life satisfaction, especially among those who perceived that the environment was not corrupt. When the corruption is wide spread in an environment, individuals including workers may feel justified to participate in corruption, which may affect how such corrupt acts affect life satisfaction. In such case, corruption may serve an economic motive rather than justice or revenge motive. The focus of the current study was to investigate the extent to which life satisfaction affects the connection of perception of organizational injustice with corrupt tendencies or revenge-motivated angle to corruption.

Generally, previous studies (e.g. Tay et al., 2014; Wu \& Zhu, 2016) on corruption and life satisfaction treated corruption as the predictor variable while life satisfaction was the outcome variable. In the current study, life satisfaction was treated as a predictor of employees' corrupt tendencies. This is because even when corruption is predicated on revenge motives, employees who are satisfied with life may be less willing to engage in corruption than those who have low life satisfaction. Apart from predicting corrupt tendencies, life satisfaction is expected to mediate the relationship between perception of organization injustice and corrupt tendencies. The following hypotheses were generated:

Hypothesis 2: Life satisfaction will have a significant inverse relationship with corrupt tendencies among employees.

Hypothesis 3: Life satisfaction will significantly mediate the relationship between perception of organizational injustice and corrupt tendencies such that life satisfaction will reduce the level at which perception of organizational injustice leads to corrupt tendencies.

Figure 1 summarizes the hypothesized relationships among the variables.

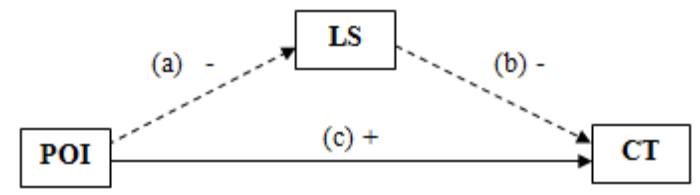

Figure 1. Summary of the hypothesized relationships among study variables.

Notes: POI $=$ Perception of organizational injustice. $\mathrm{LS}=\mathrm{Life}$ satisfaction. $\mathrm{CT}=$ Corrupt tendencies.

\section{Method}

\section{Participants and procedure}

The participants were 285 employees (188 males; 97 females), whose ages averaged 39.09 years $(S D=8.40)$ with a range of 20 to 58 years. They were selected across large sections of two public sector organizations in Nigeria. They had spent an average of 11.03 years $(\mathrm{SD}=5.99)$ with a minimum of 1 year and a maximum of 34 years on the job. Since only $3(1.0 \%)$ of the 288 employees that responded to the questionnaire indicated that they were widowed, divorced, or separated, the final analysis was restricted to the 285 participants who indicated that they were either married (219 or $76.8 \%$ ) or single (66 or $23.2 \%)$. The participants also provided information on their job level and academic qualification. There were two categories of job level: junior (205 or $72.0 \%$ ) and senior ( 80 or $28 \%$ ). In the case of academic qualification, Sixty three $(22.1 \%)$ of the respondents did not go beyond Secondary School education, $143(49.8 \%)$ had either National Diploma or Nigerian Certificate of Education, 59 (20.7\%) had either Higher National Diploma or first degree, and $21(7.4 \%)$ had postgraduate degree.

Employees in the selected organizations were intimated with the purpose of the study. They were made to understand that the study, which was designed to examine how employees respond to perceived injustice in the workplace, would not pose any adverse physical or psychological effects on them. They were free to participate in the study or not. Those who chose to participate in the study completed the informed consent form. The participants completed the questionnaire, which had the measures of perception of organizational injustice, life satisfaction, and corrupt tendencies as well as some socio-demographic variables, during office hours. Since permission was gotten from the head of personnel in the organizations, it was easy for participants to take some few minutes off their schedule to complete the questionnaire. Out of the 291 questionnaires distributed, 288 were returned but analyses were based on the responses of 285 employees. This was because 3 of the respondents were excluded from the final analyses (as stated earlier) for reasons relating to their marital status.

\section{Measures}

Perception of organizational injustice was assessed using a 13-item scale, pulled together from 3 measures of the three major dimensions of organizational injustice identified in literature: distributive injustice (Rup \& Cropanzano, 2002), interpersonal injustice (Colquitt, Conlon, Wesson, Porter \& Ng, 2001), and procedural injustice (Price \& Mueller, 1986). Items that measured distributive injustice focused the perceived fairness in the reward system. Interpersonal injustice measured the perceived quality of interpersonal relationship. Finally, the items that assessed procedural injustice were concerned with the perceived fairness in procedures of the organization. All the items were rated on a 5-oint scale $($ Never $=1$; Always $=5)$. Sample items are: "Are you treated with dignity in your workplace?", "Are you fairly rewarded in your workplace taking into account the amount of education and training that you have had?" and "Are the procedures your organization uses to make decisions fair?"

Since this study was concerned about the overall effects of perception of organizational injustice on life satisfaction and corrupt tendencies, the aggregate, rather than the segregated, scores on the measure were used in the analysis. The 13-item inventory had been used and found reliable in Nigerian samples. For example, Ogungbamila and Udegbe (2014) reported that the overall scale had a 0.77 Cronbach alpha. Ogungbamila (2017) reported a Cronbach's alpha of 0.81 . In the present study, the scale had a Cronbach's alpha of 0.87. Scores on or above the mean were interpreted as high level of organizational injustice and scores that were below the mean showed that the respondent perceived low level of organizational injustice.

Life satisfaction was measured using Diener, Emmons, Larsen and Griffin's (1985) Satisfaction with Life Scale (SWLS). SWLS was a 5-item instrument designed to measure individuals' subjective evaluation of how satisfied they are with their present state of affairs as compared with their personal standard. It was rated on a 7-point scale $(1=$ strongly disagree; strongly agree $=7$ ). Sample items are: "I 
am satisfied with life" and "If I could live my life over, I would change almost nothing" Diener et al. (1985) reported a 2-month test re-test coefficient of 0.82 and a coefficient alpha of 0.87 reliability values for the scale. The scale recorded a Cronbach's alpha of 0.89 with the present sample. Scores on SWLS were interpreted in such a way that the respondents' level of life satisfaction increased as their scores on the scale increased.

Corrupt tendencies of the participants were measured using a 9-item Corrupt Tendencies Scale (Ogungbamila \& Udegbe, 2014). It was designed to measure employees' feelings toward corruption. The participants rated their responses to each item on a 4 -point scale $(1=$ strongly disagree; $4=$ strongly agree). Sample item are: "Demanding for over reimbursement from the organization" and "Helped another person to take a property or an item that belonged to the organization".

According to previous studies that used Nigerian samples, the scale had 0.92 (Ogungbamila \& Udegbe, 2014) and 0.96 (Ogungbamila, 2017) Cronbach's alpha coefficients. With the present sample, the scale had a 0.95 Cronbach's alpha. The Corrupt Tendencies Scale was scored in such a way that score that were below the mean showed that low corrupt tendencies and scores that were up to or higher than the mean indicated that the employees had high tendencies to engage in corruption.

\section{Results}

The mean and standard deviation scores as well as the relationships among the variables in the study were calculated. The results are presented in Table 1.

As Table 1 indicates, employees' corrupt tendencies increased as their level of perception of organizational injustice increased $[r(283) .33, p<.001]$. This implied that when employees felt that how inputs were rewarded and the procedure of distributing workplace outcomes as well as the quality of interpersonal relationship enjoyed in the workplace did not meet some acceptable levels of justice and fairness, they were more likely to engage in acts of corruption than when they felt otherwise.. Life satisfaction was, however, related with low level of corrupt tendencies $[r(283)-.28, p<.01]$. This showed that employees, who felt comfortable with life, because the current state of affairs met their personal standard and expectations, were less likely to engage in corruption than those who had low life satisfaction.

Table 1. Mean, SD, and Relationships among the Variable

\begin{tabular}{|c|c|c|c|c|c|c|c|c|c|c|c|}
\hline Variables & & $M$ & $S D$ & 1 & 2 & 3 & 4 & 5 & 6 & 7 & 8 \\
\hline 1. & Age & 39.30 & 8.34 & - & & & & & & & \\
\hline 2. & Gender & - & - & -.09 & - & & & & & & \\
\hline 3. & Marital status & - & - & $.20 *$ & -.06 & - & & & & & \\
\hline 4. & Academic qualification & - & - & $.25^{* *}$ & .14 & .12 & - & & & & \\
\hline 5. & Job level & - & - & $.21 *$ & -.12 & .14 & .12 & - & & & \\
\hline 6. & Job tenure & 11.03 & 5.99 & .13 & -.06 & $.18^{*}$ & .14 & $.18^{*}$ & - & & \\
\hline 7. & Perception of organizational injustice & 28.44 & 6.12 & -.10 & .02 & .09 & -.03 & $-.19 *$ & -.07 & - & \\
\hline 8. & Life satisfaction & 21.56 & 3.41 & $.13^{*}$ & .04 & .03 & -.08 & .06 & .03 & $-.37 * * *$ & - \\
\hline 9. & Corrupt tendencies & 23.13 & 2,62 & -.02 & -.04 & -.01 & -.06 & .03 & -.07 & $.33 * * *$ & $-.28 * *$ \\
\hline
\end{tabular}

Notes: ${ }^{*} p<.05{ }^{* *} p<.01 .{ }^{* * *} p<.001 . \mathrm{N}=285$. Gender was coded male 0 ; female 1. Marital status was coded Single $0 ;$ Married 1 . Academic qualification was coded "Did Not Go beyond Secondary School Education" 0; ND or NCE 1; HND or first degree 2; postgraduate degree 3. Job level was coded junior level 0; senior level 1.

Table 2. Summary of Hierarchical Multiple Regression on Corrupt Tendencies

\begin{tabular}{|c|c|c|c|c|c|c|}
\hline Models & $\beta$ & $t$ & $\boldsymbol{R}$ & $R^{2}$ & $\Delta R^{2}$ & $F$ \\
\hline Model 1(socio-demographic variables) & - & - & .21 & .04 & .04 & $2.28^{*}$ \\
\hline Age & -.07 & -.74 & & & & \\
\hline Gender & -.06 & -.89 & & & & \\
\hline Marital status & .10 & 1.36 & & & & \\
\hline Academic qualification & -.09 & -1.21 & & & & \\
\hline Job level & -.06 & -.90 & & & & \\
\hline Job tenure &.-.11 & -1.40 & & & & \\
\hline Model 2 (Predictor variables) & - & - & .35 & .12 & .08 & $3.84^{* * *}$ \\
\hline Age & -.08 & -.77 & & & & \\
\hline Gender & -.04 & -.76 & & & & \\
\hline Marital status & .09 & 1.21 & & & & \\
\hline Academic qualification & -.07 & -.72 & & & & \\
\hline Job level & -.05 & -.87 & & & & \\
\hline Job tenure & -.10 & -.1 .34 & & & & \\
\hline Perception of organizational injustice & $.29 * *$ & $3.03 * *$ & & & & \\
\hline Life satisfaction & $-.22 * *$ & $2.30^{*}$ & & & & \\
\hline
\end{tabular}


Table 3. Summary of Baron and Kenny's Mediation Test on Corrupt Tendencies

\begin{tabular}{llllll}
\hline Predictor & Direct and Indirect Paths & $\boldsymbol{\beta}$ & $\boldsymbol{t}$ & $\boldsymbol{R}^{2}$ & $\boldsymbol{\Delta R}^{2}$ \\
\hline Perception of organizational injustice & POI to LS & $-.21^{*}$ & $-2.23^{*}$ & & \\
& LS to CT & $-.25^{* *}$ & $-2.56^{* *}$ & \\
& POI to CT (without LS) & $.37^{* *}$ & $4.02^{* *}$ & .14 & .03 \\
& POI to CT (with LS) & $-.17^{*}$ & $-2.09^{*}$ & .11 \\
\hline
\end{tabular}

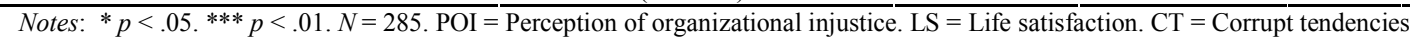

Table 2 indicates that none of socio-demographic variables influenced employees' corrupt tendencies. This implied that employees' corrupt tendencies were not restricted to age, gender, marital status, academic qualification, job level, and job tenure. All categories of employees were inclined to engage in corrupt. In terms of joint contribution, all the socio-demographic variables accounted for $4 \%$ of employees' corrupt tendencies $(R=$ $\left..21, R^{2}=.04, F=2.28, p<.05\right)$. Since none of the sociodemographic variable significantly predicted corrupt tendencies, there was no need to run multi-colinearity test on the data.

The addition of perception of organizational injustice and life satisfaction to the model, in step 2 of the analysis, changed the $\mathrm{R}$ value from .21 to .45 . This showed that the two predictor variables jointly contributed $38 \%$ to employees' level of corrupt tendencies $\left(R=.35, R^{2}=.12\right.$, $\left.\Delta R^{2}=.08, F=3.84, p<.001\right)$.

At the individual level, perception of organizational injustice was related with increased level of corrupt tendencies such that employees, who felt unjustly treated by the organization and other organization members, were more likely to engage in corruption than those who felt otherwise $(\beta=.29, t=3.03, p<.01)$. This result confirmed hypothesis 1 .

However, employees' level of corrupt tendencies reduced significantly as their level of life satisfaction increased $(\beta=-.22, t=2.30, p<.05)$. This showed that life satisfaction reduced the urge to behave dishonestly in the workplace because the employees' current state of affairs met some personal standard they set. Hypothesis 2 was, therefore, supported by the results in Table 2 .

Test of hypothesis 3

Baron and Kenny's (1986) and Sobel's (1982) mediation tests were performed to test hypothesis 3. In performing the Baron and Kenny' (1986) mediation test, (a) life satisfaction was regressed on perception of organizational injustice, (b) the extent to which life satisfaction predicted corrupt tendencies was assessed, (c) the level at which perception of organizational injustice predicted corrupt tendencies, when the effects of life satisfaction were excluded from the model, was tested, and (d) the extent to which perception of organizational injustice predicted corrupt tendencies, when the effects of life satisfaction were included, was also determined. The results are presented in Table 3.

Results in Table 3 show that life satisfaction reduced as employees reported increasing level of perceived organizational injustice $(\beta=-.21, t=-2.23, p<.05)$. Similarly, Life satisfaction significantly led to reduced level of corrupt tendencies $(\beta=-.25, t=-2.36, p<.01)$. When the effects of life satisfaction were removed from the model connecting perception of organizational injustice with corrupt tendencies, perception of organizational injustice significantly increased employees' tendencies of engaging in corruption $(\beta=.37, t=.4 .02, p<.001)$.
However, the inclusion of life satisfaction, in the model connecting perception of organizational injustice and corrupt tendencies, did not only reduce the powers of perception of organizational injustice to predict corrupt tendencies from $14 \%$ to $3 \%$, it also changed the direction of the relationship from positive to negative $(\beta=-.17, t=$ $\left.2.9, R^{2}=.03, \Delta R^{2}=.11 p<.05\right)$. This implied that when employees had favourable evaluation of their life, their level of corrupt tendencies reduced despite the being unjustly treated and rewarded in the workplace. The results in Table 3, therefore, indicate that life satisfaction mediated the relationship between perception of organizational injustice and corrupt tendencies. The results of the mediation test are graphically presented in Figure 2.

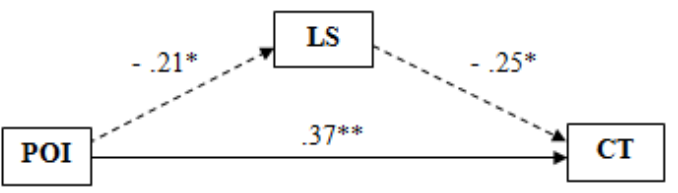

Figure 2. Summary of the hypothesized relationships among study variables.

Notes: $* p<.05 . * * p<.01 . N=285$. POI $=$ Perception of organizational injustice. $\mathrm{LS}=$ Life satisfaction. $\mathrm{CT}=$ Corrupt tendencies.

Sobel's (1982) test, which involved the division of the mediated path $(a b=-.21 \times-.25)$ by its standard error $\left(a b_{S E}\right.$ $=.023 \times .017)$, was further performed on the data to determine the strength of mediation. Results indicate that life satisfaction significantly mediated the relationship between perception of organizational injustice and corrupt tendencies by undermining the level at which perception of organizational injustice prompted employees to behave in a dishonest manner Sobel $z=8.75, p<.001$ ). This showed that when employees were satisfied with life, the tendencies to engage in dishonest behavior even when they felt unjustly rewarded and treated in the workplace was low. Therefore, life satisfaction successfully attenuated the effects of perception of organizational injustice on corrupt tendencies. Hypothesis 3 was supported.

\section{Discussion}

The major aim of this study was to investigate how perception of organizational injustice might be related with corrupt tendencies in employees. Another aim of the study was to determine whether life satisfaction would reduce corrupt tendencies despite the unfair treatment in the workplace.

In consonance with the results of previous studies (e.g. Ogungbamila \& Udegbe, 2014; Ogungbamila, 2017), a strong positive connection existed between perception of organizational injustice and employees' tendencies to engage in corruption. This supported the notion that employees react with revenge-motivated behavior in 
response to perceived organizational injustice, especially if the organization or its agents could not be exonerated from the perceive effort-reward imbalance suffered by the aggrieved employees (Ojedokun, 2010; Siegrist et al., 2004). At that point, the employees investigated in this study might have felt justified to engage in corruption to redress the perceived imbalance in the effort-reward equation.

When employees felt justified to engage in corruption, the justification might provide a basis for diffusing the fear of punishment that would have discouraged them from engaging in corruption. This may be because the employees now see themselves more as individual or collective victims of injustice and less as corrupt employees (Ogungbamila, 2017). This may explain why corrupt tendencies cut across all the participants, irrespective of their age, gender, marital status, academic qualification, job level, and job tenure. The high rate of unemployment in Nigeria, which could have made the employees "overcommitted" to the organization and less involved in dishonest activities for fear of being thrown out of employment (Siegrist et al., 2004), did not really discourage them from using corruption as a retaliatory behavior against perceived injustice. This study has shown that corruption is one of the revenge-motivated reactions of employees to perceived injustice that was targeted at balancing the effort-reward imbalance.

As expected in hypothesis 2, life satisfaction was related with reduced tendencies to engage in corruption. This implied that an increase in the level of life satisfaction was related with a reduced urge to behave dishonestly in the workplace probably because the employees' current state of affairs approximated the personal standard they set (Pavot \& Diener, 2008). Therefore, employees, who felt satisfied with their current circumstance, were less inclined to engage in corruption as a revenge-motivated behavior targeted at the organization and those responsible for the discrepancies. However, employees, who were not satisfied with their current state of affairs, might have felt justified to engage in corruption to avenge their unsatisfactory condition. They also might have seen corruption as an avenue to garner workplace resources to balance out the perceived discrepancies in their personal standard and the reality provided in the organization.

Previous studies (e.g. Tay et al., 2014; Wu \& Zhu, 2016) reported a strong inverse relationship between corruption and life satisfaction. They found that corruption brought down people's level of life satisfaction. As pointed out earlier, previous researchers treated corruption as an independent variable because they were interested in proving that low life satisfaction was one of the adverse effects of corruption. However, the current study, which treated life satisfaction as an independent variable, showed that life satisfaction could explain why poor individuals may not engage in corruption; contrary to the propositions of cost-benefit analysis of corruption. That is, irrespective of social and economic status, employees may be corrupt if their current state of life affairs do not meet up to or approximate the personal standard they set for themselves. Such personal standard may also include the ability to help others.

Though corruption has been linked with high rate of poverty and inequality (Adegboyega, 2017; Rabnawaz, 2015; Yunan \& Andini, 2018), the present study has shown that low socio-economic status may not initiate, prompt or drive corrupt tendencies in employees. Therefore, the results of the present study added to literature on the relationship between life satisfaction and corrupt tendencies, especially among employees in developing countries where majority of the citizens are poor and the poor do not have equal access to resources compared to those who are rich and influential. In addition to that, the present study has shown that employees with high socioeconomic status were also prone to corrupt if they perceive themselves as an individual or a collective victim of injustice and are less satisfied with life. Therefore, high perception of organizational injustice and low life satisfaction strongly explain why employees, who are highly placed economically and socially, may engage in corruption as a revenge-motivated behavior. Such public sector employees may also see corruption as a veritable opportunity for avenging the perceived injustice suffered by important others or groups.

Finally, life satisfaction mediated the relationship between perception of organizational injustice and corrupt tendencies in such a way that when employees were satisfied with the outcome of their subjective evaluation of their current state of affairs, their level of corrupt tendencies reduced despite being unjustly treated in the workplace. This may be because the employees trusted and, therefore, gave the organization an opportunity to redress the injustice, which might have reduced their level of retaliatory behavior and corrupt tendencies (Goergen et al., 2018).

The results of the present study generally showed that employees could be driven by other motives apart from the economic benefits of corruption (Cook, 1982; Gibbs, 1975). The present study, therefore, strengthened the position of Gorsira et al. (2018) that economic explanation for employee corruption may not hold across situations. The revenge-motivation and justice-restoring hypotheses (Goergen et al., 2018; Ogungbamila \& Udegbe, 2014; Ogungbamila, 2017) of workplace corruption has been given a boost by the results of the present study. This implied that when employees perceive injustice, they may be motivated to engage in corruption in order to protest the unfair treatment and restore the balance of justice. This motivation may be attenuated by the life satisfaction and perceived institutional or organizational trust with the expectations that the organization would engage in purposeful efforts that would redress the injustice and restore fairness.

On the practical side, the present study has shown the promising effects of life satisfaction in reducing corrupt tendencies even in the midst of perception of organizational injustice. This implies that when organizations provide employees with fair and equitable opportunities of meeting their personal goals and aspirations, which may lead to a favorable subjective evaluation of their current state of affairs, their tendencies of engaging in corruption may reduce.

The present study has implicated institutional trust in the relationships among perception of organizational injustice, life satisfaction, and corrupt tendencies. It may, therefore, be beneficial if future studies, which involve the use of vignettes, investigate the mediator and moderator roles of institutional or organizational trust on the relationships of perception of organizational injustice and life satisfaction with corrupt tendencies. Since the present study relied solely on self-report measures, which is often prone to common method variance, adopting a critical incidence technique that involves the use of vignettes may enhance the internal validity of future studies. 


\section{References}

Abraham, J., Suleeman, J., \& Takwin, B. (2018). The psychology of corruption: The role of the counterfeit self, entity self-theory, and outcome-based ethical mindset. Journal of Psychological and Educational Research, 26(2), 7-32.

Adegboyega, R. (2017). Corruption and economic growth in Nigeria: A cointegration (FM-OLS) approach. Annals of the University of Petroşani, Economics, 17(1), 5-18.

Agbo, A., \& Iwundu, E. (2016). Corruption as a propensity: Personality and motivational determinants among Nigerians. The Journal of Psycho-logy: Interdisciplinary and Applied, 150(4), 502-526. https://doi.org/10.1080/00223980.2015.1107523

Baron, R. M., \& Kenny, D. A. (1986). The moderator mediator variable distinction in social psychology research: Conceptual, strategic, and statistical considerations. Journal of Personality and Social Psychology, 51(6), 1173 - 1183.

Ciziceno, M., \& Travaglino G. A. (2019). Perceived corruption and individuals' life satisfaction: The mediating role of institutional trust. Social Indicators Research: An International and Interdisciplinary Journal for Quality-ofLife Measurement, 141(2), 685-701. https://doi.org/10.1007/s11205-018-1850-2

Colquitt, J. A., Conlon, D. E., Wesson, M. J., Porter, O. L. H., \& Ng, K. Y. (2001). On the dimensionality of organizational justice: A construct validation of a measure. The Journal of Applied Psychology, 86, 386-400. https://doi.org/10.1037/0021-9010.86.3.386

Cook, P. (1982). Research in criminal deterrence: Laying the groundwork. In N. Morris., \& M. Tonry. (Eds.) Crime and Justice: A Review of Research, Vol. 2 (pp. 211-268). Chicago, IL: The University of Chicago Press.

Dajani, M. A. Z., \& Mohamad, M. S. (2017). Perceived organisational injustice and counterproductive behaviour: The mediating role of work alienation evidence from the Egyptian public sector. International Journal of Business and Management, 12(5), 192-201. https://doi.org/10.5539/ijbm.v12n5p192

Danaeefard, H., \& Boustani, H. R. (2016). Injustice perceptions and employees misbehavior in the public organization: Exploration of mediating role of employee's cynicism to organization. International Journal of Human Capital in Urban Management, 1(1), 9-18. https://doi.org/10.7508/ijhcum.2016.01.002

Diener, E., Emmons, R. E., Larsen, R. J., \& Griffin, S. (1985). The satisfaction with life scale. Journal of Personality Assessment, 49(1), 71-75.

Diener, E., Oishi, S., \& Lucas, R. E. (2003). Personality, culture, and subjective wellbeing: Emotional and cognitive evaluations of life. Annual Review of Psychology, 54(1), 403-425.

Dong, B., Dulleck, U., \& Torgler, B. (2012). Conditional corruption. Journal of Economic Psychology, 33(3), 609627. https://doi.org/10.1016/j.joep.2011.12.001

Dupuy, K., \& Neset, S. (2018). The cognitive psychology of corruption: Micro-level explanations for unethical behaviour. Retrieved from https://www.u4.no/publications/the-cognitive-psychologyof-corruption on $20^{\text {th }}$ June, 2020.

Fišar, M., Kubák, M., Špalek, J., \& Tremewan, J. (2016). Gender differences in beliefs and actions in a framed corruption experiment. Journal of Behavioral and Experimental Economics, 63, 69-82. https://doi.org/10.1016/j.socec.2016.05.004

Gibbs, J. P. (1975). Crime, punishment, and deterrence. New York, NY: Elsevier.

Goergen, C., Pauli, J., Cerutti, P., \& Perin, M. (2018). The organizations. Justice, trust and retaliatory attitude: A study in a company in the metal-mechanic sector.

Cuadernos de Administración (Journal of Management), 34(62), 33-49.

https://doi.org/10.25100/cdea.v34i62.6930

Gorsira, M., Denkers, A., \& Huisman, W. (2018). Both sides of the coin: Motives for corruption among public officials and business employees. Journal of Business Ethics, 151(1), 179-194. https://doi.org/10.1007/s10551-016$\underline{3219-2}$

Hechanova, R., Melgar, I., Falguera, P., \& Villaverde, M. (2014). Organisational culture and workplace corruption in government hospitals. Journal of Pacific Rim Psychology, 8(2), 62-70. https://doi.org/10.1017/prp.2014.5

Heidenheimer, A. J. (2013). Political corruption: A handbook. New Brunswick, NJ: Transaction Books.

Johnston, M. (2010). Syndromes of corruption: Wealth, power, and democracy. Cambridge: Cambridge University Press.

Julián, M., \& Bonavia, T. (2020). Psychological variables related to corruption: A systematic review. Annals of Psychology, 36(2), 330-339. https://doi.org/10.6018/analesps.389371

Kaufmann, D. (1997). Corruption: The facts. Foreign Policy $107,114-131$

Lambsdorff, J. G. (2010). How corruption affects productivity. Kyklos, 56, 457-474.

Leineweber, C., Eib, C., Bernhard-Oettel, C., \& Nyberg, A. (2019). Trajectories of effort-reward imbalance in Swedish workers: Differences in demographic and workrelated factors and associations with health. Work \& Stress: An International Journal of Work, Health \& Organisations. https://doi.org/10.1080/02678373.2019.1666434

López-López, W., Bocarejo, M., Peralta, D., Pineda, C., \& Mullet, E. (2017). Mapping Colombian citizens' views regarding ordinary corruption: Threat, bribery, and the illicit sharing of confidential information. Social Indicators Research, 133(1), 259-273. https://doi.org/10.1007/s11205-016-1366-6

Ngamaba, K. H. (2014). What are the best predictors of happiness and life satisfaction for the elderly? A worldwide study across 8 regions. A paper presented at the International Conference on Geriatrics \& Gerontology between July 08 and 10, 2014 DoubleTree by Hilton Hotel Chicago-North Shore Conference Center, USA. http://dx.doi.org/10.4172/2167-7182.S1.002

Ogungbamila, B. (2017). An examination of the relationship between perceived injustice, workplace neutralization and corrupt tendencies: A study on employees in Nigeria. South Asian Journal of Management, 24(3), 7-27.

Ogungbamila, B., \& Udegbe, I. B. (2014). Gender difference in the effects of perception of organizational injustice on workplace reactivity. Europe's Journal of Psychology, 10(1), 150-167, https://doi.org/10.5964/ejop.v10i1.575

Ojedokun, O. A. (2010). Effort-reward imbalance and attitude towards unethical work behaviour among police personnel: Emotional intelligence as a moderator. Ife PsychologIA, 18(1), 137-155.

Onifade, C., \& Bodunde, H. (2009). Gender differences in students' response to corrupt practices in Nigeria. Gender \& Behaviour, 7(1), 2162-2172. https://doi.org/10.4314/gab.v7i1.45037

Pavot, W., \& Diener, E. (2008). The satisfaction with life scale and the emerging construct of life satisfaction. The Journal of Positive Psychology, 3(2), 137-152.

Price, J. L., \& Mueller, C. W. (1986). Handbook of organisational measurement. Marshfield, MA: Pittman.

Rabl, J. (2011). The impact of situational influences on corruption in organizations. Journal of Business Ethics, 100, 85-101. https://doi.org/10.1007Л10551-01 1-0768-2 
Rabnawaz, A. (2015). Corruption, inequality and economic growth. Developing Country Studies, 5(15), 106-111.

Rijckeghem C. V., \& Weder, B. (2014). Bureaucratic corruption and the rate of temptation: Do wages in the civil service affect corruption, and by how much?' Journal of Development Economics, 6(5), 307-331.

Rupp, D. E., \& Cropanzano, R. (2002). The mediating effects of social exchange relationships in predicting workplace outcomes from multifoci organizational justice. Organizational Behavior and Human Decision Processes, 89, 925-946. https://doi.org/10.1016/S07495978(02)00036-5

Saithibvongsa, P., \& JinKyo, S. (2019). Individual perceived corruption diminishes the work effectiveness and organizational performance: Public organizations in Laos. International Journal of Economics and Management, $1(1), 26-46$.

Siegrist, J. (2000). Place, social exchange and health: Proposed sociological framework. Social Science \& Medicine, 51, 1283-1293.

Siegrist, J. (2002). Effort-reward imbalance at work and health. In P. L. Perrowe, \& D. C. Ganster (Eds.), Historical and current perspectives on stress and health (pp. 261-291). Amsterdam: JAI Elsevier.

Siegrist, J., Starke, D., Chandola, T., Godin, I., Marmot, M., Niedhammer, I., \& Peter, R. (2004). The measurement of effort-reward imbalance at work: European comparisons. Social Science \& Medicine, 58, 1483-1499. https://doi.org/10.1016/S0277-9536(03)00351-4

Sobel, M. E. (1982). Asymptotic intervals for indirect effects in structural equations models. In S. Leinhart (Ed.), Sociological methodology (pp. 290 - 312). San Francisco: Jossey-Bass.

Spector, P. E., Fox, S., Penney, L. M., Bruursema, K., Goh, A., \& Kessler, S. (2006). The dimensionality of counterproductivity: Are all counterproductive behaviors created equal? Journal of Vocational Behavior, 68(3), 446-460. https://doi.org/10.1016/i.jvb2005.10.005

Šumah, Š. (2018). Corruption: Causes and consequences. Retrieved from https://www.intechopen.com/books/tradeand-global-market/corruption-causes-and-consequences on $20^{\text {th }}$ June, 2020.
Sunkanmi, O. A., \& Isola, A. L. (2014). Corruption and economic growth in Nigeria. Journal of Economics and Sustainable Development, 5(6), 45-56.

Tay, L., Herian, M., \& Diener, E. (2014). Detrimental effects of corruption on subjective well-being: Whether, how, and when. Social Psychological and Personality Science, 5(7), 751-759. https://doi.org/10.1177/1948550614528544

Tu, W., Yang, J. \& Zheng, Y. (2020, in Press). Influence of individual values on attitudes toward corruption: What undermine formal anticorruption effectiveness? Asian Journal of Social Psychology. https://doi.org/10.1111/ajsp.12402

Türedi, S., \& Altiner, A. (2016). Economic and political factors affecting corruption in developing countries. International .Journal of Economic Research, 7i1, 120 136.

World Bank Group. (2019). Poverty \& equity brief: SubSaharan Africa. Retrieved from

https://databank.worldbank.org/data/download/poverty/33EF 03BB-9722-4AE2-ABC7AA2972D68AFE/Global_POVEQ SSA.pdf on $17^{\text {th }}$ July, 2019.

Wu, Y., \& Zhu, J. (2016). When are people unhappy? Corruption experience, environment, and life satisfaction in Mainland China. Journal of Happiness Studies, 17(3), 1125-1147. https://doi.org/10.1007/s10902-015-9635-7

Yunan, Z. Y., \& Andini, A. (2018). Corruption, poverty, and economic growth: Causality studies among ASEAN Countries. Jejak Journal of Economics and Policy, 11(2), 413-428. https://doi.org/10.15294/jejakv11i2.16061

Żemojtel-Piotrowska, M., Marganski, A., Baran, T., \& Piotrowski, J. (2017). Corruption and sexual scandal: The importance of politician gender. Anales de Psicologia, $33(1), 133-141$ https://doi.org/10.6018/analesps.32.3.229171

Zhao, H., Zhang, H., \& Xu, Y. (2016). Does the dark triad of personality predict corrupt intention? The mediating role of belief in good luck. Frontiers in Psychology, 7, 1-16. https://doi.org/10.3389/fpsyg.2016.00608 